\title{
黒大豆を用いたクエン酸飲料の開発とその 健康効果
}

食品に含まれるポリフェノール類は強い抗酸化性を有することから, 広範な生理機能を示すことが知られ ており, 健康機能をもつ食品成分として注目されている。近年, 地域特産品として黒大豆の品種開発や加工 技術の開発が進みつつあり, 黒大豆は発酵原料としての利用が期待されている。本解説の著者らは黒大豆と 焼酎鈿を原料としてクエン酸の爽やかな酸味をもつ新規のクエン酸健康飲料を開発した。本解説ではこのク エン酸健康飲料の開発における研究の経過と本飲料の生理機能についてラットを用いた動物実験での結果を まとめて簡潔かつ詳細に示していただいた。醸造の技術を活用した製品開発例として, 新規製品の開発に向 けて大変に参考となる事例である。

\section{穂坂 賢 ${ }^{1}$. 吉田宗弘 ${ }^{2}$. 堤 和弘 ${ }^{3}$. 舘 博 ${ }^{1}$}

\section{はじめに}

日本人の食生活において, 大豆は様々な形で利用さ れており, 日本人のタンパク質源として重要な位置を 占めている。さらに最近では, 大豆に含有される様々 な成分の健康増進効果に注目が集まっている。たとえ ば，大豆タンパク質には LDL- コレステロール低下効 果があり，動脈硬化予防効果が期待されている ${ }^{1)}$ 。さ らに, 大豆オリゴ糖の腸内細菌叢に及ぼす影響や便通 改善効果 ${ }^{2)}$, 大豆イソフラボンのエストロゲン類似作 用 ${ }^{3)}$ も健康増進に応用できると期待されている。

一方，植物性の水溶性天然色素であるアントシアニ ン類には活性酸素消去作用があることから，これを生 活習慣病予防に応用しょうとする研究も盛んに行われ ている ${ }^{4)}$ 。大豆の中でも黒大豆は, 種皮に多量のアン トシアニン類を含有するため, これを丸ごと加工する ことによって機能性の高い食品を調製することが試み られている ${ }^{5)}$ 。そのため, 健康上の効果を期待し, こ れらの成分を含有した機能性食品や飲料が数多く製造 販売されている。

さらに, クエン酸の効果を期待した健康飲料の開発
も見られている。クエン酸は, 柑橘類などの酸味の素 になる成分であり，体内に吸収されると直接エネルギ 一として利用される。またブドウ糖が細胞内で燃焼分 解されてエネルギーとなるときに生じるピルビン酸は, 筋肉に蓄積されると一部が疲労物質である乳酸に変化 するが, クエン酸はピルビン酸を分解して乳酸の生成 を抑える働きを持っている。このような疲労に対する 予防・回復効果のほか, 体液を弱アルカリ性に保ち各 種の病気を予防する効果, カルシウムや鉄などのミネ ラルを水に溶けやすくして吸収率を高める「キレート 作用」などが知られている ${ }^{6)}$ 。

筆者らは, ポリフェノール類とクエン酸の両方を, 効率よく活かせる健康飲料の開発を考案し, 黒大豆の ポリフェノール類とクエン酸麹によるクエン酸の両方 を備えた健康飲料の開発を試み ${ }^{7,8}$, 商品化（製造特 許取得 $\left.{ }^{9}\right)$ することに成功した。開発当初（平成 18 年), ポリフェノールとクエン酸の両方を効率よく活 かした飲料についての報告は見あたらなかったが，現 在では紫黒米や赤紫蘇, あるいはアセロラやブルーベ リーを活用した飲料などの商品が製造，販売されてい るようである。

Development of the Black Soybean Beverage Containing Citric Acid and its Function for Health Masaru Hosaka $^{1)}$, Munehiro Yoshida ${ }^{2)}$, Kazuhiro Tsutsumi ${ }^{3)}$ and Hiroshi Tachi ${ }^{1)}$

${ }^{1}$ Department of Brewing and Fermentation, Junior College of Tokyo University of Agriculture

${ }^{2}$ Laboratory of Food and Nutritional Sciences, Faculty of Chemistry, Materials and Bioengineering, Kansai University

${ }^{3}$ Tsutsumi Shuzo Co. Ltd. 
本稿では開発, 商品化に成功した, 黒大豆を活かし たクエン酸飲料の製造諸条件ならびに健康効果につい て紹介する。

\section{I . 開発の背景}

本飲料の開発の発端は, 今から 8 年前の平成 18 年 の初夏のころであった。当時焼酎製造について共同で 研究を行っていた酒造会社より，「黒大豆を活用した 焼酎はできないだろうか」との相談があった。当時を 振り返ると, 酒類全体の消費数量は横ばい状態から減 少に転じ始めていたが，焼酎（本格焼酎）の消費数量 はまだ増加傾向にあった ${ }^{10)}$ 時期である。しかし焼酎 の過去（昭和 50 年代末）のブーム時では，その消費 数量が増加した期間は長く続かなかった。そのため多 くの焼酎メーカーでは, 会社経営に苦労したと言われ ている。このような過去の経緯を考えると, 当時の焼 酎消費数量の増加も 1,2 年で減少に転じ，やがては 経営を悪化させる時期が来るのではないかと予測して いた。

そのような折の相談であった。当初は黒大豆による 焼酎開発の相談であったが，色々と議論を交わす中で,
酒造会社の特性を最大限に活かし，かつ焼酎製造期以 外での「人，物」を活かせる新規の製品開発へと考え 方をシフトさせていった。「人，物を活かす」は，「休 造期の労務管理」であり,「休造期の設備の活用」で ある。これらのことをまとめて活用することが，開発 の背景にあった。

すなわち，休造期の人的パワーと設備を最大限に活 用し，酒造会社にかかる設備的な問題を最小限に抑え， 黒大豆の特性をできる限り活かし, さらに酒造会社の 白趋製造技術を活かすことにより，新規の製品を開発 することであった。この考え方を会社に提案し，今回 の製品開発につながった。

\section{II . 製造諸条件}

\section{1. 黒大豆に対する米麹の添加量の検討}

製造諸条件のうち, 原料黒大豆に対する米鳌の添 加量の検討を行った。焼酎用白麹菌（Aspergillus kawachii；ビオック社）にて製鈿した米麹（以後，ク エン酸米靝という）の酸性 $\alpha$-アミラーゼ，酸性プロ テアーゼおよび酸性カルボキシペプチダーゼ活性を第 1 表に示した。供試のクエン酸米麹の酵素活性は，一

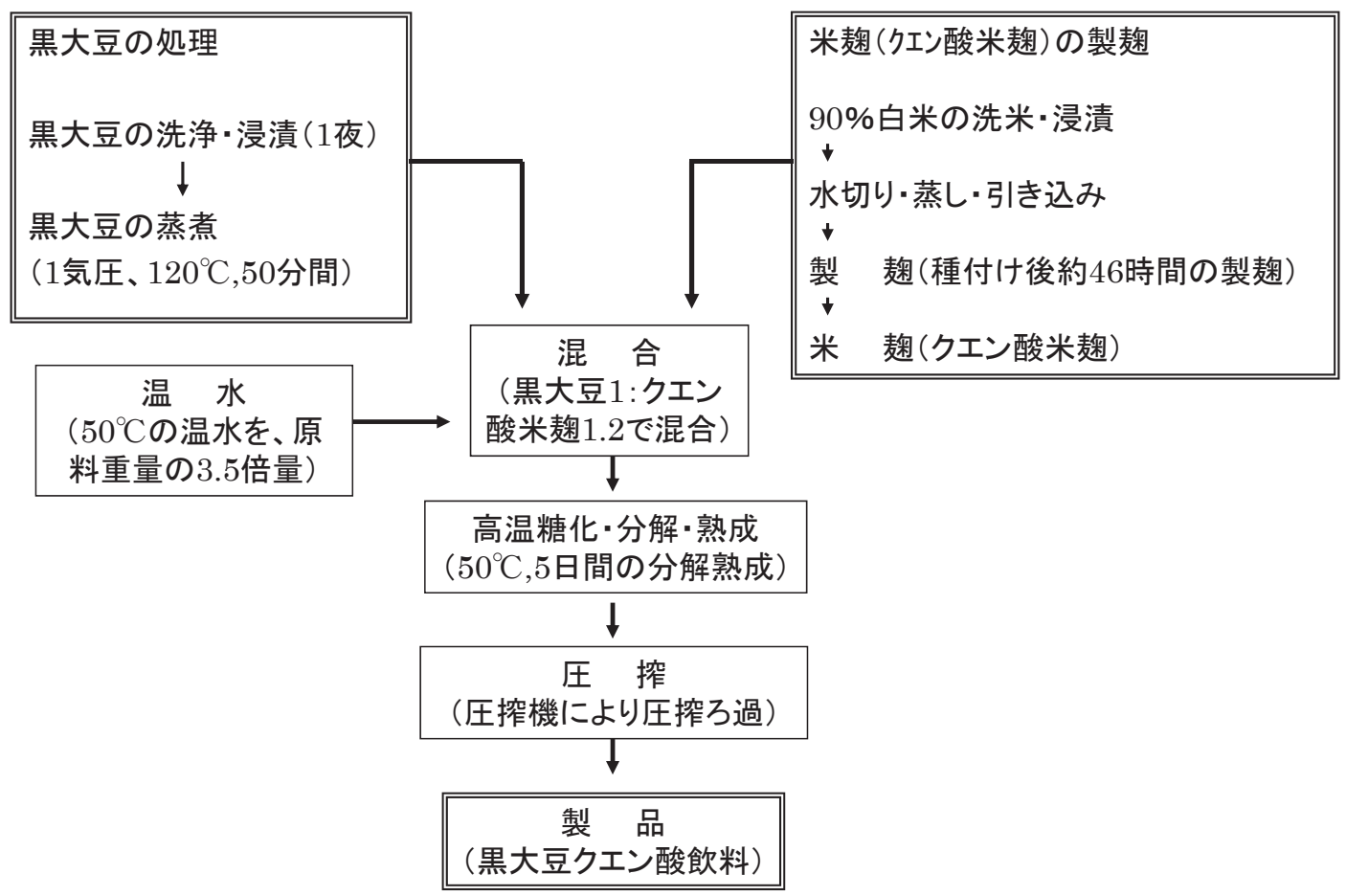

第 1 図 黒大豆クエン酸飲料の製造概略 
般的な焼酎用米鈿の酵素活性と同等であった ${ }^{11)}$ 。ま た原料である黒大豆のポリフェノール抢よびアントシ アニンの濃度を第 2 表に示した。ポリフェールは 0.45 $\mu \mathrm{mol} / \mathrm{g}$, アントシアニンは $1.59 \mu \mathrm{mol} / \mathrm{g}$ と, 国産大 豆と比較するとポリフェノールで 4.5 倍, アントシア ニンで 26.5 倍の含有量であった。

クエン酸米趜の添加量について, 原料黒大豆の重量 に対する添加重量比にて検討した。黒大豆の糖化分解 条件は, 黒大豆とクエン酸米鳌の混合重量に対し, 55 ${ }^{\circ} \mathrm{C}$ の温水を 4 倍量加え, $55^{\circ} \mathrm{C}$ で 24 時間高温糖化を行 い, その後乃紙（No.2）にてろ過し， 万液の成分分析 を行った。結果を第 3 表に示した。黒大豆 1 に対し米 麹 0.8 の添加割合では, Brix. で 4.9 , 酸度 $4.1 \mathrm{~m} \ell$, ア ミノ酸度 $1.9 \mathrm{~m} \ell$, ポリフェノール $0.02 \mu \mathrm{mol} / \mathrm{m} \ell, ア$

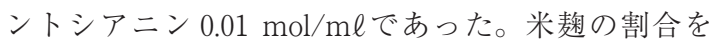
1.5 まで増加させるとポリフェノール量とアントシア ニン量はそれぞれ $0.02 \mu \mathrm{mol} / \mathrm{ml}$ と $0.01 \mu \mathrm{mol} / \mathrm{m} \ell$ は変 わらないものの, クエン酸米麹の酵素量増加により分 解が促進され, Brix. が 6.4 , 酸度 $5.7 \mathrm{~m} \ell$, アミノ酸度 $3.0 \mathrm{~m} \ell$ となった。米趜の添加量を変えてもポリフェノ ール量およびアントシアニン量に差が無いことから, ろ液の官能評価において甘味と酸味のバランスより判

第 1 表 供試白米麦匊の酵素活性

\begin{tabular}{lr} 
& (unit/g $/ k o j i)$ \\
\hline 酸性 $\alpha$-アミラーゼ & 380 \\
酸性プロテアーゼ & 27,000 \\
酸性カルボキシペプチダーゼ & 9,000 \\
\hline
\end{tabular}

第 2 表 供試黒豆中のポリフェノールおよ びアントシアニン含量

\begin{tabular}{lr} 
& $(\mu \mathrm{mol} / \mathrm{g})$ \\
\hline ポリフェノール & $0.45(0.10)$ \\
アントシアニン & $1.59(0.06)$ \\
\hline$($ ）の数值は, 大豆 (国産) & の数值を示す。
\end{tabular}

定を行い, 黒大豆に対するクエン酸米鈿の添加量は, 黒大豆 1 に対しクエン酸米趜 1.2 が適当であるとの結 果を得た。

\section{2. 原料に対する温水添加量の検討}

原料（黒大豆: クエン酸米麹 $=1: 1.2$ ） 総量に対する 温水の添加量について検討した。なお黒大豆の糖化分 解条件は, 先の試験と同様行い, 温水の添加量を原料 総量の $3 ， 3.5 ， 4 ， 4.5$ および 5 倍量にて検討を行った。 万液成分の分析結果を第 4 表に示した。温水の添加量 が 3 倍から 5 倍に増加するに従い, Brix. 度は 6.4 か ら 5.0 に, 酸度は $5.6 \mathrm{~m} \ell$ から $3.8 \mathrm{~m} \ell に, ア ア ノ$ 酸度

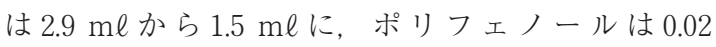
$\mu \mathrm{mol} / \mathrm{m} \ell$ から $0.01 \mu \mathrm{mol} / \mathrm{mll}$, およびアントシアニ ンは $0.01 \mu \mathrm{mol} / \mathrm{m} \ell$ か $0.01 \mu \mathrm{mol} / \mathrm{m} \ell$ 以下の值までそ れぞれ減少した。またろ液の官能評価より, 温水の添 加量 3.5 倍が, 甘味と酸味のバランスが良好であり, アミノ酸, ポリフェノールおよびアントシアニン濃度 も 3 倍の添加量と遜色ないことより, 温水の添加量 3.5 が最適との結果を得た。

\section{3. 原料の分解, 糖化温度の検討}

前実験までに $55^{\circ} \mathrm{C}, 24$ 時間の糖化条件では, 黒大 豆 1 に対しクエン酸米趎 1.2 , 総原料に対し温水添加 量 3.5 倍量が最適との結果を得た。本実験においては, さらにクエン酸米懒の酵素により，黒大豆を効率よく

第 3 表 黒豆に対する米责匊の添加量の影響

\begin{tabular}{|c|c|c|c|c|}
\hline \multirow[t]{2}{*}{ 一般成分分析 } & \multicolumn{4}{|c|}{$\begin{array}{c}\text { 米麹の添加量 } \\
\text { (対黒豆重量比) }\end{array}$} \\
\hline & 0.8 & 1.0 & 1.2 & 1.5 \\
\hline $\mathrm{pH}$ & 4.3 & 4.2 & 4.1 & 3.9 \\
\hline Brix 度 & 4.9 & 5.4 & 6.1 & 6.4 \\
\hline 酸 度 & 4.1 & 4.8 & 5.2 & 5.7 \\
\hline アミノ酸度 (ml) & 1.9 & 2.4 & 2.7 & 3.0 \\
\hline ポリフェノール $(\mu \mathrm{mol} / \mathrm{ml})$ & 0.02 & 0.02 & 0.02 & 0.02 \\
\hline アントシアニン $(\mu \mathrm{mol} / \mathrm{ml})$ & 0.01 & 0.01 & 0.01 & 0.01 \\
\hline
\end{tabular}

第 4 表 原料総量に対する温水の添加量の影響

\begin{tabular}{lrrrrr}
\hline & \multicolumn{5}{c}{ 一温水の添加量 $($ 対原料総量比) } \\
\cline { 2 - 6 } & 3.0 & 3.5 & 4.0 & 4.5 & 5.0 \\
\hline $\mathrm{pH}$ & 3.9 & 4.1 & 4.2 & 4.3 & 4.3 \\
Brix 度 & 6.4 & 6.1 & 5.7 & 5.3 & 5.0 \\
酸 度 $\quad(\mathrm{ml})$ & 5.6 & 5.2 & 4.7 & 4.2 & 3.8 \\
アミノ酸度 $(\mathrm{ml})$ & 2.9 & 2.6 & 2.4 & 2.0 & 1.5 \\
ポリフェノール $(\mu \mathrm{mol} / \mathrm{ml})$ & 0.02 & 0.02 & 0.01 & 0.01 & 0.01 \\
アントシアニン $(\mu \mathrm{mol} / \mathrm{ml})$ & 0.01 & 0.01 & 0.01 & $<0.01$ & $<0.01$ \\
\hline
\end{tabular}


第 5 表 各糖化温度に扮ける分解効果

\begin{tabular}{lccrrr}
\hline \multirow{2}{*}{ 一般成分分析 } & \multicolumn{5}{c}{ 糖化温度 $\left({ }^{\circ} \mathrm{C}\right)$} \\
\cline { 2 - 6 } & 30 & 40 & 55 & 60 & 80 \\
\hline Brix 度 & 0.1 & 3.2 & 2.5 & 1.0 & 0.1 \\
アミノ酸度 $(\mathrm{ml})$ & 2.3 & 2.7 & 2.6 & 0.7 & 0.5 \\
\hline
\end{tabular}

糖化, 分解する温度について検討した。30〜 $80^{\circ} \mathrm{C}$ の各 糖化温度における分解効果について, 24 時間分解後 の分解物のBrix 度拉よびアミノ酸度を測定し，その 結果を第 5 表に示した。

分解温度 $30^{\circ} \mathrm{C}$ は, Brix 度 0.1, アミノ酸度 $2.3 \mathrm{~m} \ell$ であったが, $40^{\circ} \mathrm{C}$ では, Brix 度 3.2, アミノ酸度 2.7 $\mathrm{m} \ell$ へと増加した。さらに $55^{\circ} \mathrm{C}$ では, Brix 度 2.5, ア ミノ酸度 $2.6 \mathrm{~m} \ell$ と減少し, $60^{\circ} \mathrm{C}, 80^{\circ} \mathrm{C}$ と分解温度を 上昇させるに従って Brix 度挹よびアミノ酸度は減少 した。これはクエン酸酸性下でかつ温度が上昇するこ とにより, クエン酸米麦匊中の酵素が失活したためによ ると考えられる。これらの結果より最適分解温度は, $40^{\circ} \mathrm{C}$ が適当といえるが，実際の製造を考えた場合，微 生物污染の面ではやや疑問が残る。

本実験では微生物污染について検討していないが, 一般にクエン酸酸性下では細菌污染は見られないが, 酵母による污染が懸念される。特に栄養が豊富であれ ばなおさらである。しかし酵母污染は，50ㄷ 温度により十分抑制することが可能である ${ }^{12)}$ 。従っ て分解温度の面から見ると, $40^{\circ} \mathrm{C}$ が最適と考えられる が，前述のごとく，微生物管理をも考慮すると $50^{\circ} \mathrm{C}$ から $55^{\circ} \mathrm{C}$ の範囲での温度帯での原料分解, 糖化が適 当であると考えられた。

\section{4. 分解熟成期間の検討}

前実験までにクエン酸米麹使用量, 温水添加量㧍よ び分解温度について検討した。本実験においては, さ らに原料からの成分の効率よい利用を目的に, 分解熟 成日数の検討を行った。第 6 表に糖化温度 $50^{\circ} \mathrm{C}$ での 分解熟成日数に扔ける， 万液成分の分析值を示した。 当然のことながら分解熟成日数が長くなればなるほど, 分解熟成は進むが, 分解熟成日数 5 日目では, 酸度 $7.6 \mathrm{~m} \ell$, アアミノ酸度 $5.6 \mathrm{~m} \ell$, ポリフェノール 0.08

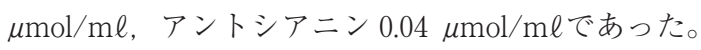
7 日目では, 酸度 $7.8 \mathrm{~m} \ell$, アミノ酸度 $5.8 \mathrm{~m} \ell$, ポリ フェノール $0.08 \mu \mathrm{mol} / \mathrm{ml}$, アントシアニン 0.05 $\mathrm{mol} / \mathrm{m \ell}$ と, 5 日目よりも僅かに増加した。
第 6 表 糖化温度 $50^{\circ} \mathrm{C}$ での分解熟成日数の影響

\begin{tabular}{lcccc}
\hline \multirow{2}{*}{ 一般成分分析 } & \multicolumn{4}{c}{ 分解熟成日数 (日) } \\
\cline { 2 - 6 } & 1 & 3 & 5 & 7 \\
\hline $\mathrm{pH}$ & 4.3 & 4.3 & 4.2 & 4.1 \\
$\mathrm{Brix}$ 度 & 5.3 & 6.6 & 8.5 & 9.6 \\
酸 度 $(\mathrm{ml})$ & 6.2 & 6.8 & 7.6 & 7.8 \\
アミノ酸度 $(\mathrm{ml})$ & 2.5 & 3.4 & 5.6 & 5.8 \\
ポリフェノール $(\mu \mathrm{mol} / \mathrm{ml})$ & 0.02 & 0.05 & 0.08 & 0.08 \\
アントシアニン $(\mu \mathrm{mol} / \mathrm{ml})$ & 0.01 & 0.02 & 0.04 & 0.05 \\
\hline
\end{tabular}

この結果から, アミノ酸量, ポリフェノールおよび アントシアニン量が 5 日目と 7 日目では大差ないこと より, 分解熟成に要する日数は 5 日目でほぼ完了した ものと考えられる。従って分解熟成期間については, 5 日間が適当であると考えられた。

\section{5. 実地製造試験}

前項までの実験結果を基に, 原料総量 $300 \mathrm{~kg}$ での 実地製造試験を行った。 $50^{\circ} \mathrm{C}, 5$ 日間分解熟成させた 後, 藪田式の圧搾機（ヤブ夕式自動モロミ搾機, BP60/30 段型）にて分解液を得た。得た分解液（以後, 黒大豆クエン酸飲料という）について，一般成分分析， アミノ酸組成分析，有機酸組成分析およびミネラル成 分分析を行った。各々の分析結果を第 7 表から第 10 表に示した。

一般成分分析では，酸度 $10.5 \mathrm{~m} \ell ， ア ミ ノ$ 酸度 5.6 $\mathrm{m} \ell$, タンパク質 $2.4 \%$, 炭水化物 $11.1 \%$ ，エネルギ ー $54 \mathrm{Kcal}$, ポリフェノール $0.08 \mu \mathrm{mol} / \mathrm{m} \ell$, アントシ アニン $0.06 \mu \mathrm{mol} / \mathrm{m} \ell$ との結果を得た。アミノ酸, ポ リフェノールおよびアントシアニンも実験值と同様の 含有量を示し, 十分な分解熟成が行なわれたといえよ う。アミノ酸組成分析結果から, グルタミン酸が 166.2 mg\%，ロイシンが 135.5 mg\%，リジンが 132.5

第 7 表 実地製造による一般成分分析值

\begin{tabular}{lr}
\hline \multicolumn{1}{c}{ 成 分 } & 分析值 \\
\hline $\mathrm{pH}$ & 4.10 \\
酸 度 $(\mathrm{ml})$ & 10.50 \\
アミノ酸度 $(\mathrm{ml})$ & 5.60 \\
タンパク質 $(\%)$ & 2.40 \\
炭水化物 $(\%)$ & 11.10 \\
脂 質 $(\%)$ & 0.10 \\
灰 分 $(\%)$ & 0.40 \\
エネルギー $(\mathrm{Kcal} / 100 \mathrm{ml})$ & 54.00 \\
ポリフェノール $(\mu \mathrm{mol} / \mathrm{ml})$ & 0.08 \\
アントシアニン $(\mu \mathrm{mol} / \mathrm{ml})$ & 0.06 \\
\hline
\end{tabular}


第 8 表 実地製造によるアミノ酸成分分析值

\begin{tabular}{lr} 
& $(\mathrm{mg} \%)$ \\
\hline アミノ酸 & 分析值 \\
\hline アスパラギン酸 & 84.10 \\
スレオニン & 52.10 \\
セリン & 51.80 \\
グルタミン酸 & 166.20 \\
プロリン & 97.90 \\
グリシン & 25.10 \\
アラニン & 66.60 \\
バリン & 53.10 \\
メチオニン & 35.50 \\
イソロイシン & 20.60 \\
ロイシン & 135.50 \\
チロシン & 64.70 \\
フェニルアラニン & 77.50 \\
ヒスチジン & 98.30 \\
リジン & 132.50 \\
アルギニン & 52.40 \\
\hline 合 計 & $1,113.90$ \\
\hline
\end{tabular}

第 9 表 実地製造による有機酸成分分析值

\begin{tabular}{lr} 
& $(\mathrm{mg} \%)$ \\
\hline \multicolumn{1}{c}{ 有機酸 } & \multicolumn{1}{c}{ 分析值 } \\
\hline クエン酸 & 347.5 \\
リンゴ酸 & 13.6 \\
コハク酸 & 2.6 \\
乳 酸 & 34.9 \\
フマル酸 & 1.3 \\
\hline
\end{tabular}

第 10 表 実地製造による無機塩類成分分析値

\begin{tabular}{lr} 
& $(\mathrm{ppm})$ \\
\hline \multicolumn{1}{c}{ 無機塩類 } & \multicolumn{1}{c}{ 分析值 } \\
\hline カリウム & 1460.0 \\
ナトリウム & 26.0 \\
カルシウム & 71.0 \\
マグネシウム & 188.0 \\
鉄 & 4.2 \\
\hline
\end{tabular}

$\mathrm{mg} \%$ と, 他のアミノ酸（ヒスチジン $98.3 \mathrm{mg} \%$ イソ ロイシン $20.6 \mathrm{mg} \%$ ）に比べ多く含有していることも 明らかになった。また有機酸組成分析結果から, クエ ン酸米麹を使用していることもあり, クエン酸が全有 機酸量の $87 \%$ (347.5 mg\%) も含有していた。さら に無機塩類成分分析結果より，カリウムが $1460 \mathrm{ppm}$, 次いでマグネシウム 188 ppmであり, カリウムが無 機塩類の $83.5 \%$ を占めていた。

このように実地製造試験から, 黒大豆クエン酸飲料 は，クエン酸主体の酸味を呈する飲料であり， かつ原
料由来のポリフェノール，アントシアニンを含むほか, アミノ酸も $1,113 \mathrm{mg} \%$ 含有し, カリウムを多く含む 飲料であった。

したがって我々が考案した, 黒大豆を用いクエン酸 米趋で糖化分解熟成し，製造したものは，従来にない 新しいクエン酸, ポリフェノール, アントシアニンを 含有する飲料であるといえる。

\section{III. 健康への効果}

黒大豆クエン酸料の機能性を明らかにする目的で, ラットに段階的に黒大豆クエン酸飲料を投与し, 血清 および肝臓成分を測定した。

6 週齢の Wistar 系雄ラット（平均体重 99.6 g) 24 匹を 6 匹ずつ 4 群に分け，1 群にはAIN93G 基本飼 料 ${ }^{13)}$, 他の 3 群には基本飼料 $100 \mathrm{~g}$ に対して黒大豆ク エン酸飲料を $4,16,40 \mathrm{~m} \ell$ の割合で混合した飼料を 投与し， 4 週間の自由摂食法にて飼育した。飼育期間 終了後, エーテル麻酔下で開腹し, 腹部大動脈より採 血するとともに, 肝臓, 白色脂肪組織（腎臓周辺, 精 巣周辺および腸間膜), 褐色脂肪組織を採取した。

採取した血液については, 血清生化学（中性脂肪濃 度（TG）, 総コレステロール濃度, アスパラギン酸ア ミノトランスフェラーゼ活性（AST)，アラニンアミ ノトランスフェラーゼ活性 (ALT) ) 検査を行った。 また採取した肝臓のタンパク質濃度と脂質濃度を測定 した。各測定結果は分散分析と Tukey-Kramer 検定 を用いて解析し, 有意水準 $5 \%$ として群間の比較を行 った。

4 週間の飼育期間中の体重増加量と飼料効率を第 11 表に示した。飼料効率において各群に差は生じなかっ たが, 体重においては, 対照群である $0 \mathrm{~m} \ell$ 群に比較 して, 黒大豆クエン酸飲料 $4 \mathrm{~m} \ell$ 投与群の増加量が有 意に大きかった。しかし, 黒大豆クエン酸飲料投与量

第 11 表 4 週間の飼育期間中のラットの体重増加と 飼料効率

\begin{tabular}{ccc}
\hline 群 & 体重 $(\mathrm{g})$ & $\begin{array}{c}\text { 飼料効率 } \\
(\text { 体重増 }(\mathrm{g}) / \text { 飼料摂取量 }(\mathrm{g}))\end{array}$ \\
\hline $0 \mathrm{ml}$ & $180.5 \pm 4.1^{\mathrm{a}}$ & $0.37 \pm 0.01^{\mathrm{a}}$ \\
$4 \mathrm{ml}$ & $199.6 \pm 2.9^{\mathrm{b}}$ & $0.38 \pm 0.01^{\mathrm{a}}$ \\
$16 \mathrm{ml}$ & $194.2 \pm 4.1^{\mathrm{ab}}$ & $0.37 \pm 0.01^{\mathrm{a}}$ \\
$40 \mathrm{ml}$ & $184.3 \pm 6.1^{\mathrm{ab}}$ & $0.38 \pm 0.01^{\mathrm{a}}$ \\
\hline
\end{tabular}

平均值士標準誤差 $(n=6)$, 同じ列の中で異なる添字のあ る平均值の組み合わせは, 統計的に有意 $(\mathrm{p}<0.05)$ である。 


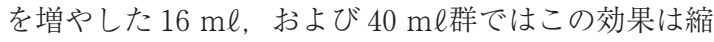
小し, 対照群との差は有意ではなかった。第 12 表に は飼育期間終了後の各群ラットの肝臓と白色, および 褐色脂肪組織重量を体重 $100 \mathrm{~g}$ 当たりに換算してまと めたものを示した。黒大豆クエン酸飲料 $16 \mathrm{~m} \ell$ 投与群 に执いて, 白色脂肪組織重量がやや増加する傾向があ つたが，有意水準を $5 \%$ とした場合は，いずれの組 織の重量においても, 各群間に差を検出することはで きなかった。第 13 表には, 血清生化学検査の一部を まとめたものを示した。黒大豆クエン酸飲料投与は量 依存的に血清 AST と ALT 活性, およびTG 濃度を 低下させ, $40 \mathrm{~m} \ell$ 投与群と $0 \mathrm{~m} \ell$ 群との間に有意差を 検出した。しかし, 総コレステロール濃度をはじめと する他の測定項目に関しては, 群間に有意な差は存在 せず，黒大豆クエン酸飲料投与の影響は認められなか った。第 14 表には, 飼育期間終了後の各群ラットか ら採取した肝臓中のタンパク質濃度と脂質濃度の測定 結果をまとめたものを示した。黒大豆クエン酸飲料投 与は量依存的に肝臟のタンパク質濃度を増加, 脂質濃 度を減少させた。

以上の結果より，基本飼料 $100 \mathrm{~g}$ に黒大豆クエン酸 飲料 $4 \mathrm{~m} \ell$ を混合することによって, 体重の有意な増 加が生じた。飼料効率に差がなかったことから，この 現象は摂食量の増加によると判断できる。すなわち, 黒大豆クエン酸飲料には食欲増進効果があるといえる。

第 12 表 飼育期間終了後の各群のラットの肝臟と白 色および褐色脂肪組織重量

\begin{tabular}{cccc}
\hline 群 & $\begin{array}{c}\text { 肝臟重量 } \\
(\mathrm{g} / \text { 体重 } 100 \mathrm{~g})\end{array}$ & $\begin{array}{c}\text { 白色脂肪組織 } \\
(\mathrm{g} / \text { 体重 } 100 \mathrm{~g})\end{array}$ & $\begin{array}{c}\text { 褐色脂肪組織 } \\
(\mathrm{g} / \text { 体重 } 100 \mathrm{~g})\end{array}$ \\
\hline $0 \mathrm{ml}$ & $3.83 \pm 0.16$ & $4.01 \pm 0.21$ & $0.11 \pm 0.01$ \\
$4 \mathrm{ml}$ & $3.70 \pm 0.09$ & $4.04 \pm 0.32$ & $0.11 \pm 0.02$ \\
$16 \mathrm{ml}$ & $3.68 \pm 0.04$ & $4.88 \pm 0.28$ & $0.11 \pm 0.02$ \\
$40 \mathrm{ml}$ & $3.80 \pm 0.06$ & $4.24 \pm 0.31$ & $0.10 \pm 0.01$ \\
\hline
\end{tabular}

平均值 標準誤差 $(n=6)$
しかし，この効果は黒大豆クエン酸飲料の投与量を増 大させると縮小した。飲料中のどのような成分がラッ トの食欲を増進したかは不明であるが，投与量を増大 させると効果が縮小することから，味または臭いとい った官能的な要因が関わっている可能性も考えられる。

一方, 黒大豆クエン酸飲料投与により, 血清 AST と ALT 活性, 血清 TG, および肝臓脂質濃度は低下 し, 肝臓タンパク質濃度は逆に増加した。この効果は 量依存的であることから, 前述の食欲増進効果とは独 立したものと考えられる。血清 AST とALT は肝細 胞からの逸脱酵素であることから ${ }^{14)}$, これらの值が 変動することは, 肝細胞質の血清への逸脱量の変動, もしくは肝細胞内における両酵素活性值の変動を意味 する。本実験においては, 黒大豆クエン酸飲料投与群 の血清 AST とALT の活性值は基本飼料投与群より も低下していた。一般には, 血清 AST と ALT 活性 值の上昇は肝細胞質逸脱量の増大, すなわち肝細胞に 損傷が起こっていることを意味するが，本実験におい て, 血清 AST と ALT 活性值が最大であった基本飼 料投与群に肝障害が発生しているとは考え難いことか ら, 黒大豆クエン酸飲料投与による血清 AST, およ びALT 活性值の低下は肝細胞内における両酵素活性 值の低下を意味するものと思われる。

AST とALT の役割はアミノ酸であるアスパラギ

第 14 表 ラットより採取した肝臟中のタンパク質お よび脂質含有量

\begin{tabular}{ccc}
\hline 群 & タンパク質 $(\%)$ & 脂 質 $(\%)$ \\
\hline $0 \mathrm{ml}$ & $18.2 \pm 0.8^{\mathrm{a}}$ & $6.4 \pm 0.3^{\mathrm{b}}$ \\
$4 \mathrm{ml}$ & $18.6 \pm 0.5^{\mathrm{a}}$ & $5.5 \pm 0.8^{\mathrm{ab}}$ \\
$16 \mathrm{ml}$ & $19.2 \pm 1.0^{\mathrm{ab}}$ & $4.9 \pm 0.4^{\mathrm{a}}$ \\
$40 \mathrm{ml}$ & $20.8 \pm 1.1^{\mathrm{a}}$ & $4.8 \pm 0.3^{\mathrm{a}}$ \\
\hline
\end{tabular}

平均值士標準誤差 $(\mathrm{n}=6)$, 同じ列の中で異なる添字の ある平均値の組み合わせは, 統計的に有意 $(\mathrm{p}<0.05)$ で ある。

第 13 表 飼育期間終了後の各群のラットより採取した血液の血清生化学值

\begin{tabular}{ccccc}
\hline 群 & AST $(\mathrm{IU} / \mathrm{ml})$ & ALT $(\mathrm{IU} / \mathrm{ml})$ & 中性脂肪 $(\mathrm{mg} / \mathrm{dl})$ & $\begin{array}{c}\text { 総コレステロール } \\
(\mathrm{mg} / \mathrm{dl})\end{array}$ \\
\hline $0 \mathrm{ml}$ & $89 \pm 3^{\mathrm{b}}$ & $52 \pm 3^{\mathrm{b}}$ & $67 \pm 9^{\mathrm{b}}$ & $73 \pm 2^{\mathrm{a}}$ \\
$4 \mathrm{ml}$ & $81 \pm 3^{\mathrm{ab}}$ & $45 \pm 3^{\mathrm{ab}}$ & $48 \pm 5^{\mathrm{ab}}$ & $73 \pm 6^{\mathrm{a}}$ \\
$16 \mathrm{ml}$ & $79 \pm 2^{\mathrm{ab}}$ & $47 \pm 4^{\mathrm{ab}}$ & $46 \pm 6^{\mathrm{ab}}$ & $72 \pm 2^{\mathrm{a}}$ \\
$40 \mathrm{ml}$ & $70 \pm 3^{\mathrm{a}}$ & $37 \pm 2^{\mathrm{a}}$ & $31 \pm 4^{\mathrm{a}}$ & $75 \pm 5^{\mathrm{a}}$ \\
\hline
\end{tabular}

平均值 標準誤差 $(\mathrm{n}=6)$, 同じ列の中で異なる添字のある平均值の組み合わせは, 統計的に有意 $(\mathrm{p}<0.05)$ である。 
ン酸やグルタミン酸を有機酸に変換し, TCA サイク ルに導入することにある。かりに黒大豆クエン酸飲料 投与によって肝臟中の AST と ALT 活性が低下して いたとするならば，肝臓アミノ酸プール中の主要アミ ノ酸であるグルタミン酸とアスパラギン酸の異化代謝, すなわちエネルギーへの変換は抑制されることになる。 アミノ酸からのエネルギー産生量が低下した場合, 不 足したエネルギーは脂肪を分解することによって補わ れるであろう。すなわち, 黒大豆クエン酸飲料投与に よって肝㵴脂質と血清 TG が減少したのは, アミノ酸 の異化代謝が抑制されたために生じたと解釈すること ができる。

黒大豆クエン酸飲料投与によって AST と ALT の 活性低下が生じた理由は不明である。これら両酵素は いずれもビタミン B6 を補酵素としており，B6 が不 足したときには活性低下が起こる ${ }^{15)}$ 。天然物や薬物 の中にはB6 の吸収抑制, 排泄促進など, 食品に含ま れる B6 の有効性を低下させるものが存在することが 知られている ${ }^{16)}$ 。このようなアンチ B6 物質を摂取し た場合には，血清の AST や ALT 活性は低下する ${ }^{17)}$ したがって，黒大豆クエン酸飲料中にはこのようなア ンチ B6 物質が存在している可能性が考えられる。ビ タミン B6 は必須の栄養素であり，極度に不足すれば 様々な弊害が生じる。しかし, 黒大豆クエン酸飲料 $40 \mathrm{ml}$ 投与群においても, 体重増加の点で飲料非投与 群と遜色ないことから, B6 不足の悪影響は起こって いないと判断できる。すなわち, 今回の投与量の範囲 内であれば, 黒大豆クエン酸飲料投与は肝蔵の AST とALT の活性を少し低下させることによって, 脂質 の蓄積を防止するという好ましい効果のみを発現させ るといえる。今回の実験ではラット飼料 $100 \mathrm{~g}$ に対し て 4 40 meの黒大豆クエン酸飲料を投与した。ヒト が1日に摂取する食事量が乾燥重量に換算して 400 $500 \mathrm{~g}$ であることを考慮すると，この投与量はヒトに 換算して1日あたり 16 200 ml程度になる。ヒトに おいてもこの範囲の摂取であれば，黒大豆クエン酸飲 料の摂取は健康に対して好ましい影響を与えるであろ うと考えている。

\section{まとめ}

以上紹介したごとく，焼酎メーカーの技術力等を活 かし, 黒大豆のポリフェノールとクエン酸米趜のクエ
ン酸の両方を, 効率よく活かせる健康飲料の開発を考 え, それに伴う製造概略を考案し, 黒大豆のポリフエ ノールとクエン酸米麹によるクエン酸の両方を備えた 健康飲料の開発, 商品化に成功した。さらにラットを 用いて黒大豆クエン酸飲料の機能性の検証を行ったと

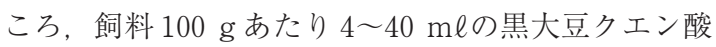
飲料の投与は, 量依存的に血清 AST, ALT 活性, 中 性脂肪濃度, および肝臓脂質濃度を低下させ, 逆に肝 臓タンパク質濃度を増加させた。黒大豆クエン酸飲料 の摂取は肝臓の AST と ALT 活性を低下させること によって,アミノ酸の異化代謝を抑制し, 結果として 脂肪の代謝を促進したと考えられた。

以上より, 黒大豆クエン酸飲料の摂取は肝臓および 血清脂質濃度の低下という好ましい健康効果を起こす 可能性があると判断した。

$\langle 1$ 東京農業大学短期大学部醉造学科 2 関西大学化学生命工学部食品工学研究室

3 堤酒造 (株) $\rangle$

\section{参考文献}

1）山本孝史：ヒト血漿コレステロール濃度に及ぼ す大豆タンパク質の効果, 栄食誌, 44, 155162 (1991)

2）原淑恵, 池田なぎさ, 初見健一, 渡部恂子, 飯 野久和, 光岡知足: 大豆オリゴ糖の低投与量に よる便性状改善効果, 栄養学雑誌, 55, 79-84 (1997)

3） 戸田登志也：大豆イソフラボン応用商品開発の 歴史と今後の課題, 食品工業, 50 (17), 66-72 (2007)

4）松本均：植物ポリフェノールの多様な機能性の 解明 (3), カシスポリフェノールの視覚改善機 能, バイオサイエンスとインダストリー, 64, 558-561 (2006)

5）渡辺聡, 太養寺真弓, 浅野聡 : 黒大豆を使用し た米辛口味増中のアントシアニンの消長, 味増 の科学と技術, 55, 360-364（2007）

6）長田正松，小島徹：クエン酸で医者いらず，日 東書院（2003）

7）穂坂賢, 数岡孝幸, 堤和弘, 上田康弘, 舘博, 安藤達彦, 福永健治, 吉田宗弘: 黒豆を用いた クエン酸䣷の開発, 日健医杂誰誌, 15 (3), 36-37 (2006)

8）穂坂賢, 数岡孝幸, 堤和弘, 上田康弘, 舘博, 
安藤達彦, 福永健治, 吉田宗弘：黒豆を用いた クエン酸酢の開発，日健医杂隹誌，17(2)， 19-24 (2008)

9）堤和弘, 穂坂賢：「大豆類クエン酸飲料及びそ の製造方法」，特許第 4592106 号（2010）

10） http://www.nta.go.jp/shiraberu/senmonjoho/ sake/shiori-gaikyo/shiori/2012

11）注解編集委員会編：第四回改正国税庁所定分析 法注解，日本醸造協会（1993）

12）食品分析法編集委員会編：食品分析法, 光琳 (1984)

13) Reeves PG, Nielson FH, Fahey GC Jr: AIN-93 purified diets for laboratory rodents, Final report of the American Institute of Nutrition adhoc writing committee on the reformulation of the AIN-76A rodent diet, J. Nutr, 123, 19391951 (1993)

14）金井正光編集：臨床検査法提要第 32 版, 金原 出版, 610-615（2005）

15) Okada M, Goda H, Kondo Y, Murakami Y, Shibuya M: Effect of exercise on the metabolism of vitamin B6 and some PLP-enzymes in young rats fed a restricted vitamin B6 diet, J. Nutr. Sci. Vitaminol, 47, 116-121（2001）

16) Klosterman HJ: Vitamin B6 antagonists of natural origin, Methods Enzymol, 62, 483-495 (1979)

17) Rumsby PC, Shepherd DM: The effect of drugs on vitamin B6 function in the rat, Biochem Pharmacol, 29, 3097-3102 (1980) 